\title{
АНТИОКСИДАНТНЫЕ СВОЙСТВА ОРГАНИЧЕСКИХ ДИ- И ТРИСУЛЬФИДОВ
}

\author{
В.П. Осипова' \\ ${ }^{1}$ Федеральный исследовательский центр ЮНЦ РАН, \\ 344006, Россия, г. Ростов-на-Дону, просп. Чехова, д. 41. \\ ${ }^{2}$ Астраханский государственный технический университет, \\ 414056, Россия, г. Астрахань, ул. Татищева, д.16 .
}

DOI: 10.19163/MedChemRussia2021-2021-118

E-mail: osipova_vp@mail.ru

Перспективный подход в области создания новых фармакологически активных соединений заключается в получении политопных гетерофункциональных структур, содержащих различные биомиметические редокс-активные фрагменты с терапевтической активностью направленного действия. В работе проведена комплексная оценка антиоксидантной активности природных сераорганических соединений и их синтетических аналогов (алифатические и ароматические ди-и трисульфиды) на различных модельных системах in vitro. Методами, основанными на реакциях переноса атомов водорода и электронов (ДФПГ-, CUPRAC- и FRAP-тесты), исследована восстановительная активность соединений и показано, что способностью выступать донорами протонов и электронов в ДФПГ- и CUPRAC-тестах обладают только органические ди- и трисульфиды, имеющие в структуре HO- и HS-группы. В реакции восстановления $\mathrm{Fe}^{3+}$ (FRAP-тест) алифатические олигосульфиды не проявляют активности, а ароматические - значительно меньшую, чем водорастворимый аналог витамина Е - тролокс. Определение $\mathrm{Fe}^{2+}$-хелатирующей активности ди- и трисульфидов свидетельствует о большей возможности $\mathrm{MeS}_{3} \mathrm{Pr}$ выступать в качестве потенциального хелатирующего агента. В данном тесте фенолсодержащие сераорганические соединения, наоборот, не показывают высокой $\mathrm{Fe}^{2+}$-хелатирующей активности. Установлена антирадикальная и СОД-протекторная активность ди- и трисульфидов по способности утилизировать $\mathrm{O}_{2}^{-}$, генерированный электрохимически, в ферментативной системе ксантин/ксантиноксидаза, в модельной системе окисления адреналина в щелочной среде в присутствии и без биопрепарата (гомогенат печени гидробионтов). Отмечено ингибирующее действие органических олигосульфидов в процессе накопления первичных и вторичных продуктов пероксидного окисления цис-9-октадеценовой (олеиновой) кислоты и липидов печени гидробионтов. На основании комплекса проведённых исследований антиоксидантной активности алифатических и ароматических ди- и трисульфидов выявлены наиболее эффективные соединения, которые могут быть рекомендованы для практического применения.

Работа выполнена при поддержке Российского научного фонда

(грант № 20-13-00084).

$$
-118-
$$

